\title{
Promoting NK cell trafficking to improve therapeutic effect of NK cell therapy on osteosarcoma
}

\author{
Yuanzheng Yang ${ }^{1}$, Nancy Gordon², Eugenie S Kleinerman², Gangxiong Huang ${ }^{2 *}$ \\ From 30th Annual Meeting and Associated Programs of the Society for Immunotherapy of Cancer \\ (SITC 2015) \\ National Harbor, MD, USA. 4-8 November 2015
}

\section{Background}

Despite the ability of NK cells to kill cancer cells, NK cell-based immunotherapy has resulted in limited clinical benefit. This is largely due to the poor capacity of adoptively transferred NK cells to home to tumors. We have shown that NK cells are able to kill osteosarcoma (OS) cells in vitro in a dose-dependent manner, indicating that recruiting more NK cells to OS lung metastasis in vivo may help to achieve greater therapeutic benefit. NK cell trafficking is mediated by specific chemokine receptors expressed on NK cells, but the specific receptors necessary for NK cell migration to solid tumors including OS are ill-defined.

\section{Methods}

In this study, we demonstrate that the specific chemokine receptor, CXCR2, enhances the migration and infiltration of adoptively transferred NK cells to OS lung metastases in mice.

\section{Results}

NK cells have low level expression of CXCR2 and less than $10 \%$ of NK cells isolated from human peripheral blood mononuclear cells are CXCR2 ${ }^{+}$. However, selection for an enriched $\mathrm{CXCR} 2^{+} \mathrm{NK}$ cell population before NK cell transfer to mice bearing OS lung metastases demonstrated that $\mathrm{CXCR}^{+}{ }^{+} \mathrm{NK}$ cells have increased tumor infiltration compared to control NK cells. Additionally, over-expression of CXCR2 on NK-92 (NK-92-CXCR2) cells promotes their migration to OS cell conditioned medium in vitro, and enhances their infiltration to lung metastases in vivo.

2University of Texas MD Anderson Cancer Center, Houston, TX, USA Full list of author information is available at the end of the article
Further, adoptive transfer of NK-92-CXCR2 resulted in improved therapeutic effect on established OS lung metastases.

\section{Conclusions}

Given our demonstration of the critical role of CXCR2 in NK cell migration to tumors, our ongoing work aims to develop a strategy to promote NK cell trafficking to OS lung metastases by inducing the expression of CXCR2 on primary human NK cells.

\section{Authors' details \\ ${ }^{1}$ MD Anderson Cancer Center, Houston, TX, USA. ${ }^{2}$ University of Texas MD Anderson Cancer Center, Houston, TX, USA.}

Published: 4 November 2015

doi:10.1186/2051-1426-3-S2-P24

Cite this article as: Yang et al:: Promoting NK cell trafficking to improve therapeutic effect of NK cell therapy on osteosarcoma. Journal for ImmunoTherapy of Cancer 2015 3(Suppl 2):P24.

Submit your next manuscript to BioMed Central and take full advantage of:

- Convenient online submission

- Thorough peer review

- No space constraints or color figure charges

- Immediate publication on acceptance

- Inclusion in PubMed, CAS, Scopus and Google Scholar

- Research which is freely available for redistribution

Submit your manuscript at www.biomedcentral.com/submit
() Biomed Central 